\title{
Uvular necrosis as a cause of throat discomfort after endotracheal intubation
}

\author{
Mian Harris Iftikhar, ${ }^{1}$ Fazal I Raziq, ${ }^{2}$ Heather Laird-Fick'
}

'Department of Internal Medicine, Michigan State University, East Lansing, Michigan, USA

${ }^{2}$ College of Human Medicine, Michigan State University, East Lansing, Michigan, USA

\section{Correspondence to}

Dr Fazal I Raziq, Iraziq.fazal462@gmail.com

Accepted 19 June 2019

\section{DESCRIPTION}

Throat discomfort after orotracheal or nasotracheal procedures is relatively common, and usually due to pharyngeal irritation. We describe a rare case of uvular necrosis as a cause of throat discomfort after endotracheal intubation (shown in figure 1).

A 69-year-old man with a medical history significant for severe aortic stenosis, coronary artery disease and hypertension presented to the emergency department with chief complaint of shortness of breath. Patient reported that he over-exerted himself at the gym and felt so short of breath that he had to call emergency medical staff. Patient was brought to the emergency department where he was found to have a systolic blood pressure of $230 \mathrm{mmHg}$ and diastolic blood pressure of $120 \mathrm{~mm} \mathrm{Hg}$. Chest X-ray was significant for pulmonary oedema. Non-invasive positive pressure ventilation and nitroglycerine drip were initiated. Symptoms did not improve, and he was intubated. After receiving etomidate and rocuronium, Macintosh blades 3 were used to introduce a 7.5-French endotracheal tube. Intubation was successful in first attempt and chest X-ray confirmed proper position precluding the need to readjust the endotracheal tube. In the intensive care unit, he was treated

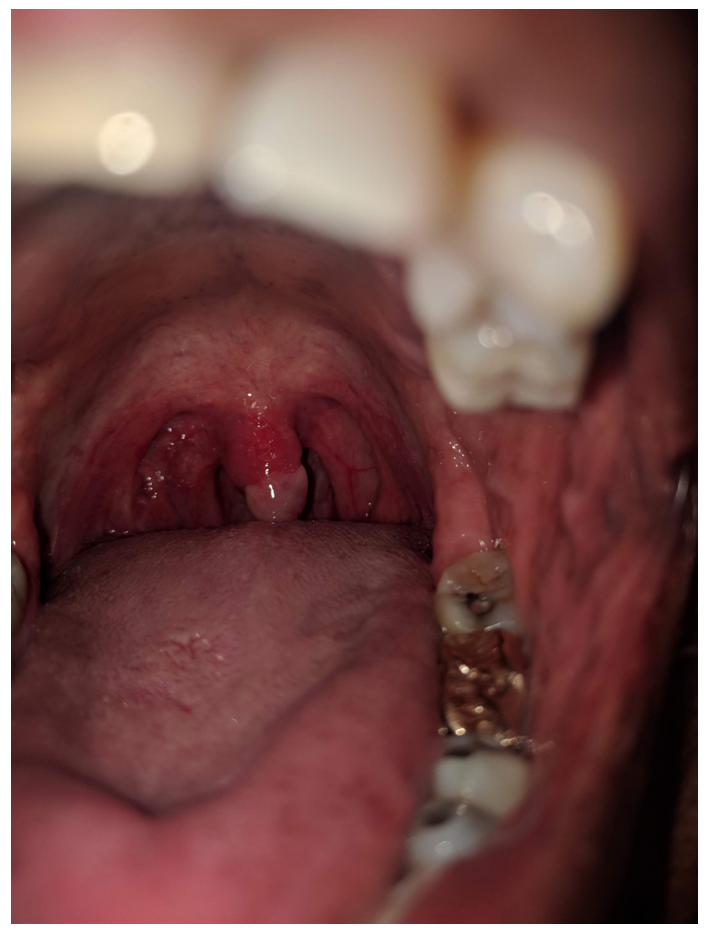

Figure 1 Uvular necrosis as a cause of throat discomfort after endotracheal intubation. with nicardipine drip and diuresis for pulmonary oedema. He was extubated after 36 hours. A few hours later he reported throat discomfort, feeling his uvula was larger and touching the back of his tongue. On examination, pharyngeal erythema and blanching of the lower half of the uvula were noted, consistent with uvular necrosis. Patient received acetaminophen and lozenges for symptom management. He was discharged home and on follow-up 1 week later patient reported that his symptoms had resolved and the necrosed part of uvula had sloughed off.

Uvular necrosis has been described after endotracheal intubation, upper gastrointestinal endoscopy, bronchoscopy via nasal approach and vigorous suctioning. Emmett et al suggested that men are at a higher risk of developing uvular oedema or necrosis owing to the bulkier tongue and palate with significantly more non-fat tissue in the neck. ${ }^{1} 2$ Patients with elongated uvula are also predisposed to uvular necrosis. ${ }^{3}$ It has been hypothesised that compression of the uvula against the pharynx or hard palate results in impaired blood flow and eventually necrosis. ${ }^{45}$ Interestingly, uvular necrosis has been seen in procedures lasting only $15 \mathrm{~min} .{ }^{6}$ Most of the cases described had scopes/tubes inserted orally, however this complication was also seen in patient who underwent nasal bronchoscopy ${ }^{3}$; the supine positioning of the patient was thought to be responsible for this complication.

Case reports have suggested symptomatic management with acetaminophen, steroids, antihistamines and topical epinephrine. The necrotic portion of the uvula sloughs off within 2 weeks without any further complications. Surgical resection of necrosed uvula was tried in one case report ${ }^{7}$; immediate resolution of foreign body sensation was achieved; however, sore throat persisted for more than a week.

\section{Learning points}

Uvular necrosis may be a cause of throat discomfort after endotracheal intubation.

- Symptomatic management with acetaminophen, steroids, antihistamines and topical epinephrine is generally sufficient. The necrotic portion of the uvula usually sloughs off within 2 weeks.

- It is suggested that during bronchoscopy, intubation or endoscopy, the tube or scope should be placed to one side of the midline to prevent damage to the uvula. 
It is suggested that during bronchoscopy, intubation or endoscopy, the tube or scope should be placed to one side of the midline to prevent damage to the uvula. ${ }^{3}$ Blind and aggressive suctioning should also be avoided. ${ }^{6}$

Contributors The case report was written by MHI. The case report was edited by FIR and $\mathrm{HL}-\mathrm{F}$. The patient was in the direct care of MHI.

Funding The authors have not declared a specific grant for this research from any funding agency in the public, commercial or not-for-profit sectors.

Competing interests None declared.

Patient consent for publication Obtained.

Provenance and peer review Not commissioned; externally peer reviewed.

\section{REFERENCES}

1 Emmett SR, Lloyd SD, Johnston MN. Uvular trauma from a laryngeal mask. Br J Anaesth 2012;109:468-9.

2 Whittle AT, Marshall I, Mortimore IL, et al. Neck soft tissue and fat distribution: comparison between normal men and women by magnetic resonance imaging. Thorax 1999;54:323-8.

3 Sunio LK, Contractor TA, Chacon G. Uvular necrosis as an unusual complication of bronchoscopy via the nasal approach. Respir Care 2011;56:695-7.

4 Atkinson CJ, Rangasami J. Uvula necrosis - an unusual cause of severe postoperative sore throat. . BJA: British Journal of Anaesthesia, 2006:97. 426-7.

5 Evans DP, Lo BM, Bm L. Uvular necrosis after orotracheal intubation. Am J Emerg Med 2009;27:631.e3-4.

6 Tang SJ, Kanwal F, Gralnek IM. Uvular necrosis after upper endoscopy: a case report and review of the literature. Endoscopy 2002;34:585-7.

7 Calikapan GT, Karakus F. Uvula necrosis after endotracheal intubation for rhinoplasty. Aesthetic Plast Surg 2008;32:710-1.

Copyright 2019 BMJ Publishing Group. All rights reserved. For permission to reuse any of this content visit

https://www.bmj.com/company/products-services/rights-and-licensing/permissions/

BMJ Case Report Fellows may re-use this article for personal use and teaching without any further permission.

Become a Fellow of BMJ Case Reports today and you can:

- Submit as many cases as you like

- Enjoy fast sympathetic peer review and rapid publication of accepted articles

Access all the published articles

Re-use any of the published material for personal use and teaching without further permission

\section{Customer Service}

If you have any further queries about your subscription, please contact our customer services team on +44 (0) 2071111105 or via email at support@bmj.com.

Visit casereports.bmj.com for more articles like this and to become a Fellow 